\title{
Inflow of foreign direct investment
}

\section{Chunlai Chen}

\section{Introduction}

The global financial and economic crisis that started in 2008, triggered by the US sub-prime crisis, which began in the summer of 2007, has had an enormous negative impact on the world economy. The growth rate of global real gross domestic product (GDP) dropped from 5.2 per cent in 2007 to 3.2 per cent in 2008. It is expected that the world economy will contract by 1.3 per cent in 2009 (IMF 2009). The current global financial and economic crisis (hereafter 'the current crisis') has also generated a huge negative impact on flows of global foreign direct investment (FDI). World FDI flows declined sharply from a historic high of US $\$ 1833$ billion in 2007 to US $\$ 1449$ billion in 2008 - a decrease of 21 per cent. As the full impact of the current crisis materialises, world FDI flows are expected to decline further in 2009 (UNCTAD 2009).

As the world's third-largest and fastest-growing economy-and the largest FDI recipient among the developing countries - China is not immune from the current crisis. China's GDP growth rate dropped from 11.4 per cent in 2007 to 9.6 per cent in 2008 and, according to the International Monetary Fund (IMF 2009), China's economy is expected to grow by 6.5 per cent in 2009, although the Chinese Government has set a growth target of 8 per cent for the year. Surprisingly, the current crisis had only a moderate impact on FDI inflows into China in 2008. FDI inflows into China (excluding those into financial sectors - the banking and insurance industries) increased by 24 per cent, from US $\$ 75$ billion in 2007 to US $\$ 92$ billion in 2008. As the current crisis worsened in the second half of 2008, however, the negative impact on FDI inflows into China gradually became apparent. Since October 2008, FDI inflows into China have declined for seven consecutive months, compared with the same period a year earlier. 
The current crisis has had and will continue to have a negative impact on the world economy and on global FDI flows. What, however, will be the impact of the current crisis on FDI inflows into China? This is the key question that this chapter seeks to answer. The chapter is structured as follows. The next section discusses the mechanism of how the current crisis affects FDI flows by analysing the impact on the magnitude of FDI flows and on different types of FDI. This section provides a theoretical and analytical framework for the analysis in the next section of the impact of the current crisis on FDI inflows into China. Section three first presents a brief introduction to FDI inflows into China for the past three decades and describes the impact of the current crisis up to the first quarter of 2009. It then provides more detailed discussions about the impact of the current crisis on FDI inflows into China by analysing the nature and charactersistics of FDI in China, aiming to predict the impact of the current crisis. Based on the above analysis and discussion, section four provides some estimations for FDI inflows into China in 2009, while section five concludes the chapter.

\section{How the current crisis affects FDI flows}

\section{The impact on the magnitude of FDI flows}

After a sharp decline in 2001-03, global FDI flows increased rapidly and experienced a period of high growth during 2003-07, reaching a historic high of US $\$ 1,833$ billion in 2007 This trend came to an end in 2008 (Figure 15.1), when global FDI inflows declined by 21 per cent.

The current crisis began in the industrialised countries, although it is spreading rapidly to developing countries. Industrialised countries have therefore been hit directly by the current crisis, while developing countries have been affected indirectly. As a result, FDI inflows into industrialised countries declined sharply from US $\$ 1248$ billion in 2007 to US $\$ 840$ billion in 2008 - a drop of 33 per cent. In contrast, FDI inflows into developing countries remained stable, increasing by 3.6 per cent, from US $\$ 500$ billion in 2007 to US $\$ 518$ billion in 2008 (Figure 15.1). 
Figure 15.1 Global FDI inflows (at current prices)

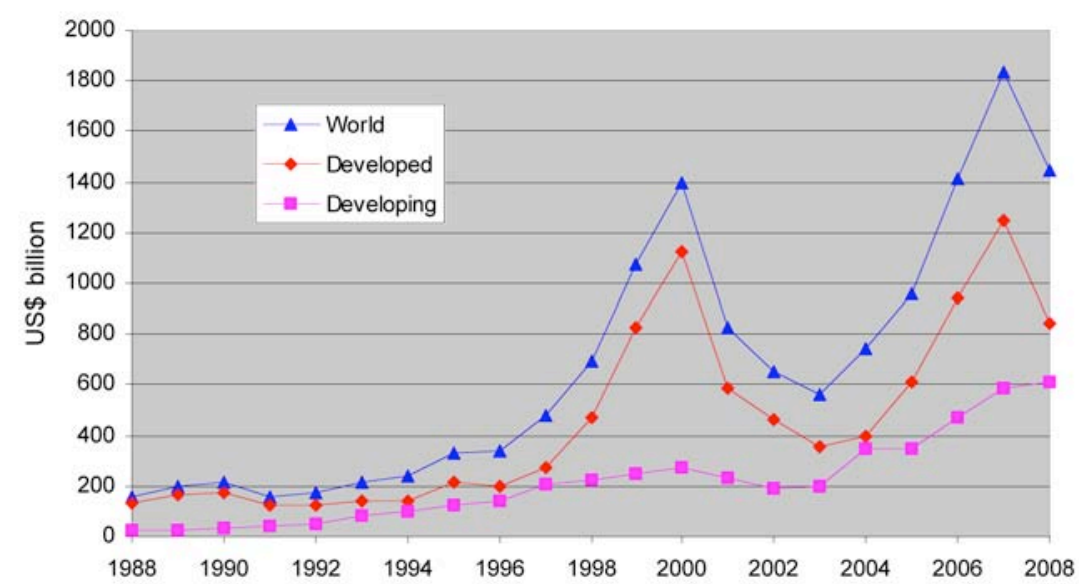

Sources: United Nations Conference on Trade and Development (UNCTAD) various issues, World Investment Report, United Nations Publications, New York and Geneva; United Nations Conference on Trade and Development (UNCTAD) 2009, Assessing the Impact of the Current Financial and Economic Crisis on Global FDI Flows, United Nations, New York and Geneva, viewed 21 May 2009, <http://www.unctad.org/en/docs/webdiaeia20091_en.pdf>

The current crisis affects FDI flows in three main aspects. It affects multinational enterprises' (MNEs) capacity to invest as a result of reduced availability of finance internally and externally. It affects MNEs' propensity to invest due to gloomy economic and market prospects. And it affects MNEs' risk-taking behaviour through the scaling back of existing investment plans due to a high level of perceived risk and uncertainty (UNCTAD 2009).

First, the environment has deteriorated rapidly across financial markets worldwide and has negatively affected MNEs' capacity to invest as tighter credit conditions and lower corporate profits reduce MNEs' financial resources for investment projects at home and abroad. On the one hand, credit has become less abundant and more expensive. The external funding environment for non-financial companies has deteriorated markedly since mid-2008, making it more difficult for them to invest in foreign operations or to make cross-border merger and acquisition deals. On the other hand, the poor earnings of large companies in a broad range of industries in the United States, Europe and Japan reduce the companies' self-financing capabilities. At the same time, the sharp decline (more than 40 per cent) in stock markets worldwide has reduced MNEs' ability to turn to stock markets for financing purposes and to leverage their cross-border merger and acquisition activities using stock shares (UNCTAD 2009). 
Second, the sharp economic recession worldwide, especially in a number of industrial countries such as the United States, Japan, Germany and the United Kingdom, and a heightened appreciation of risk have also reduced MNEs' propensity to invest in further expansion of production capacity domestically and internationally (UNCTAD 2009). According to the latest IMF (2009) forecasts, global output is expected to contract by 1.3 per cent in 2009, and industrialised countries are expected to contract by 3.8 per cent. Deep recessions are forecast for all major industrialised economies. The United States is expected to contract by 2.8 per cent in 2009, the Euro area by 4.2 per cent, the United Kingdom by 4.1 per cent, Japan by 6.2 per cent and other advanced economies by 3.9 per cent. As a result, FDI flows in industrialised countries are expected to decline further by a large amount in 2009.

The economic growth for developing economies is expected to slow substantially, from 6.1 per cent in 2008 to 1.6 per cent in 2009. Among the developing economies, those in Asia are expected to grow by 4.8 per cent, which is much lower than the growth rates of 10.6 per cent in 2007 and 7.7 per cent in 2008. Compared with industrialised economies, however, in the Asian developing economies economic growth is more resilient. Therefore, FDI flows in developing economies as a whole are expected to decline in 2009; however, this decline is expected to be moderate.

Third, the current crisis could also affect MNEs' risk-taking behaviour. MNEs' investment plans could be scaled back, especially in industrialised countries, due to a high level of perceived risk and uncertainty, in order to develop resilience to possible worst-case scenarios regarding financial and economic conditions.

Therefore, as the full consequences of the current crisis for MNEs' investment expenditure continue to unfold, there are reasons to expect that global FDI flows will decline further in 2009. Based on information from the UN Conference on Trade and Development (UNCTAD 2009), global FDI flows are expected to decline by 25 per cent in 2009 to about US\$1000 billion-driven mainly by a large decline in FDI flows in industrialised countries, while developing countries are expected to witness a moderate decline. 


\section{The impact on different types of FDI flows}

The current crisis has had and will continue to have a negative impact on global FDI flows. However, the impact differs according to the types and entry modes of FDI.

In terms of the types, FDI can be classified as efficiency seeking (mostly export oriented), market seeking (market oriented) and resource seeking (mostly export oriented). All three types are impacted by the current crisis, but the magnitude of the impact differs for different types of FDI in different locations.

The FDI type most directly affected has been market-seeking projects, especially those aimed at industrialised countries. As industrialised countries are expected to experience negative growth in 2009, MNEs are restraining the launching of new projects aimed at increasing their market-oriented production capabilities. MNEs might, however, remain more committed to capacity expansion in developing countries. This commitment might, however, weaken in 2009 as growth slows in developing countries due to a decline in the value of their exports as a result of weakening external demand from industrialised countries and a fall in commodity and energy prices (UNCTAD 2009).

The impact of the current crisis on efficiency-seeking FDI is more difficult to assess. On the one hand, this type of FDI will suffer globally from the decline in the MNEs' financial capabilities. On the other hand, many MNEs might be compelled by the continuing crisis to restructure their international activities to cut costs and boost overall efficiency. This means they might close or downsize obsolete or non-cost-competitive facilities (often located in industrialised counties); however, they might also open new cost-efficient facilities, especially in developing countries, or shift production facilities from industrialised to developing countries (UNCTAD 2009). ${ }^{1}$

Resource-seeking FDI could suffer, at least in the short run, from the decline in global demand and consequently in prices, with particularly negative effects on resource-rich developing countries. Resource-seeking FDI will, however, rise quickly again once the current recession is over, as rapidly rising global demand triggers imbalances in commodity markets, boosting prices and leading MNEs to launch many new projects. 
In terms of the entry modes, FDI can take the form of greenfield investment and cross-border mergers and acquisitions. Greenfield investment is financed by equity capital, reinvested earnings and intracompany loans (between a parent company and a subsidiary). Crossborder mergers and acquisitions can be financed in several ways, including through FDI (the purchase of foreign equity shares at least 10 per cent of the total equity), portfolio equity investments (less than 10 per cent of the total equity), domestically raised capital and capital raised from international capital markets. Therefore, not all cross-border mergers and acquisitions are financed through FDI; however, in industrialised countries, most are.

There is evidence that cross-border mergers and acquisitions have been sharply affected as a direct consequence of the current crisis. Crossborder mergers and acquisitions declined from US\$1637 billion in 2007 to US $\$ 1184$ billion in 2008 . This sharp decline was due mainly to the fact that leveraged buy-outs - a common transaction method in mergers and acquisitions - fell considerably due to weakened world stock markets (UNCTAD 2009). The decline in cross-border mergers and acquisitions is of utmost importance for FDI flows, especially for FDI flows in industrialised countries, which are strongly correlated with cross-border mergers and acquisitions.

Greenfield investments seemed to be resilient to the crisis in 2008 . According to UNCTAD (2009), at the end of October, the number of greenfield investments since the beginning of 2008 was already more than 13000 , exceeding the level registered for the whole of 2007. The current crisis might, however, have some negative impact on greenfield investments in 2009 as the world recession worsens. Compared with crossborder mergers and acquisitions, however, the impact of the current crisis on greenfield FDI is relatively moderate.

Therefore, in terms of the types of FDI, the current crisis will have more direct negative impacts on FDI inflows into industrialised countries for market-seeking FDI and efficiency-seeking FDI, while the negative impact on FDI inflows into developing countries will be small for marketseeking FDI and moderate for efficiency-seeking FDI. In terms of the entry modes, the current crisis will have more direct negative impacts on crossborder mergers and acquisitions, while the impact on greenfield FDI will be moderate. 


\section{The impact of the current crisis on FDI inflows into China}

As the largest FDI recipient among the developing countries, China will undoubtedly be affected by the current crisis. What, however, will be the impacts on FDI inflows into China? This section will analyse both the nature of FDI and the special characteristics of FDI in China.

\section{The trend of FDI inflows into China}

In the past three decades, China has attracted a large volume of FDI inflows. The growth of FDI inflows into China from 1982 to 2008 can be broadly divided into three phases: the experimental phase from 1982 to 1991; the boom phase from 1992 to 2001; and the post-World Trade Organisation (WTO) phase from 2002 to 2008 (Figure 15.2).

\section{Figure 15.2 FDI inflows into China (at current prices)}

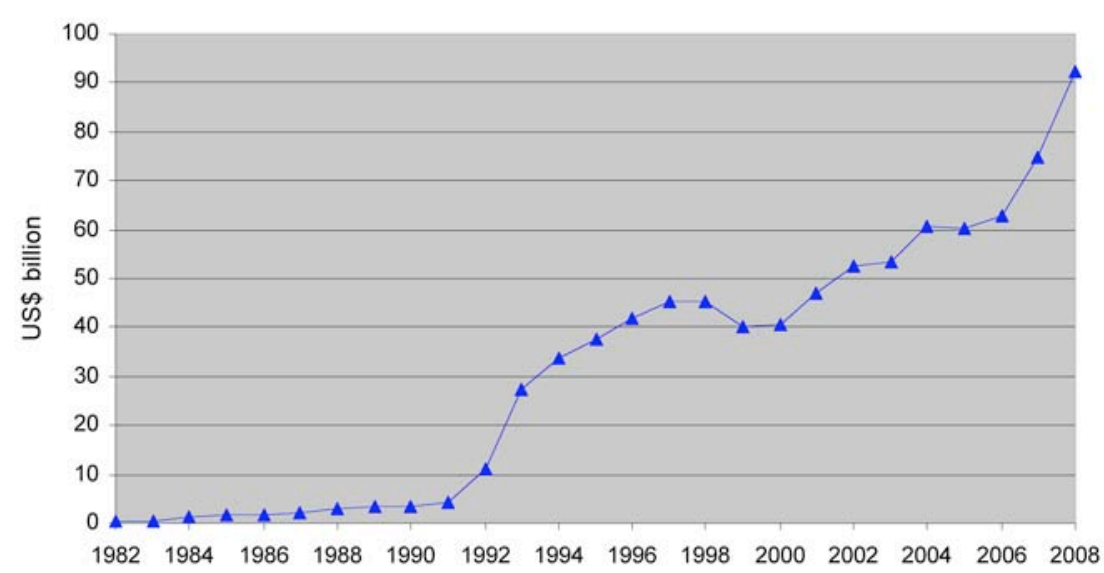

Sources: National Bureau of Statistics (NBS) various issues, China Statistical Yearbook, China Statistics Press, Beijing; Ministry of Commerce (MOFCOM) 2009a, 'FDI statistics', Invest in China, Ministry of Commerce, Beijing, viewed 21 May 2009, <http://www.fdi.gov.cn/pub/ FDI_EN/Statistics/FDIStatistics/default.htm >

During the experimental phase, FDI inflows into China were at low levels but grew steadily. In the second phase, FDI inflows increased very rapidly. FDI inflows into China slowed, however, after 1997 and declined in 1999 and 2000 - due mainly to the East Asian financial crisis. Since China's entry into the WTO in 2001, with the implementation of its WTO commitments and broader and deeper liberalisation in trade and 
investment, China's economy has been growing very rapidly. As a result, FDI inflows into China present an increasing trend-rising from US $\$ 47$ billion in 2001 to US\$75 billion in 2007. In 2008, despite the current crisis and the sharp decline in world FDI, FDI inflows into China increased by 23.58 per cent to reach US $\$ 92$ billion. $^{2}$

The current crisis has, however, had gradual and progressive negative impacts on FDI inflows into China since the second quarter and especially since October 2008. Based on the quarterly data, FDI inflows into China declined continuously in 2008 (Figure 15.3). FDI inflows into China decreased by 8.9 per cent and by 11.96 per cent in the second and third quarters, respectively, compared with those in the pervious quarters. The negative impact of the crisis on FDI inflows into China started to worsen in October 2008.

\section{Figure 15.3 Quarterly FDI inflows into China (at current prices)}

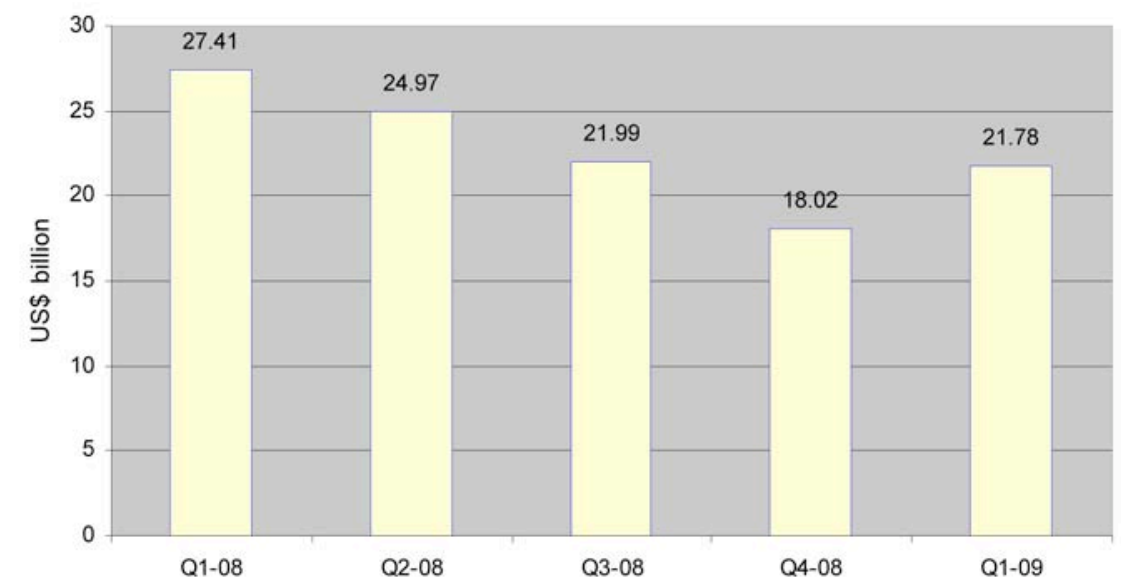

Sources: Ministry of Commerce (MOFCOM) 2009a, 'FDI statistics', Invest in China, Ministry of Commerce, Beijing, viewed 21 May 2009, <http://www.fdi.gov.cn/pub/FDI_EN/Statistics/ FDIStatistics/default.htm>

In the first quarter of 2009, FDI inflows into China were US\$22 billion, increasing 21 per cent from those in the fourth quarter, but still lower than those in the first and second quarters of 2008. It is, however, a positive sign of recovery - from a declining trend for three consecutive quarters to an increasing trend. 


\section{The composition of FDI sources in China}

FDI in China is overwhelmingly dominated by developing source economies, particularly the Asian newly industrialising economies (NIEs). During the period 1992-2008, developing economies accounted for 77 per cent of the total accumulated FDI inflows into China, while industrialised economies accounted for only 23 per cent. Among the developing economies, Hong Kong is the largest single investor (41 per cent), Taiwan (5.86 per cent), South Korea ( 4.9 per cent), Singapore ( 4.5 per cent) and ASEAN+4 (1.6 per cent). Among the industrialised economies, Japan (7.5 per cent) and the United States (7.0 per cent) are the largest investors, while the European Union-15 as a group accounted for 7.2 per cent of the total accumulated FDI inflows into China. ${ }^{3}$ Tax havens, for example Virgin Islands (10.2 per cent) were the immediate source of some investment. These have been counted as developing countries.

There are two interesting points about the annual FDI inflows into China by developing and industrialised economies during the period 1992-2008 (Figure 15.4). First, FDI inflows into China slowed and then declined during 1997-2000. This was caused entirely by the decline of FDI inflows from developing economies due to the East Asian financial crisis. The East Asian financial crisis, which started in 1997 and lasted until the early 2000s, substantially weakened the capacity for outward investment of the Asian developing economies. As a result, FDI inflows into China from these economies declined substantially during 1997-2000. During this period, however, FDI inflows into China from industrialised economies were relatively stable at about US $\$ 12$ billion.

Second, after China's accession into the WTO, FDI inflows into China increased rapidly, which was almost entirely the result of the large increase of FDI inflows from developing economies - from US\$33 billion in 2001 to US $\$ 80$ billion in 2008, with an annual growth rate of 13 per cent. FDI inflows from industrialised economies, however, increased only marginally during 2002-05, and then declined during 2006-08. As a result, the share of developing economies in total FDI inflows into China increased from 75 per cent in 1992-2001 to 80 per cent in 2002-08, while the share of industrialised economies declined from 25 per cent to 20 per cent in the same period. 


\section{Figure 15.4 FDI inflows into China by source economies} (at current prices)

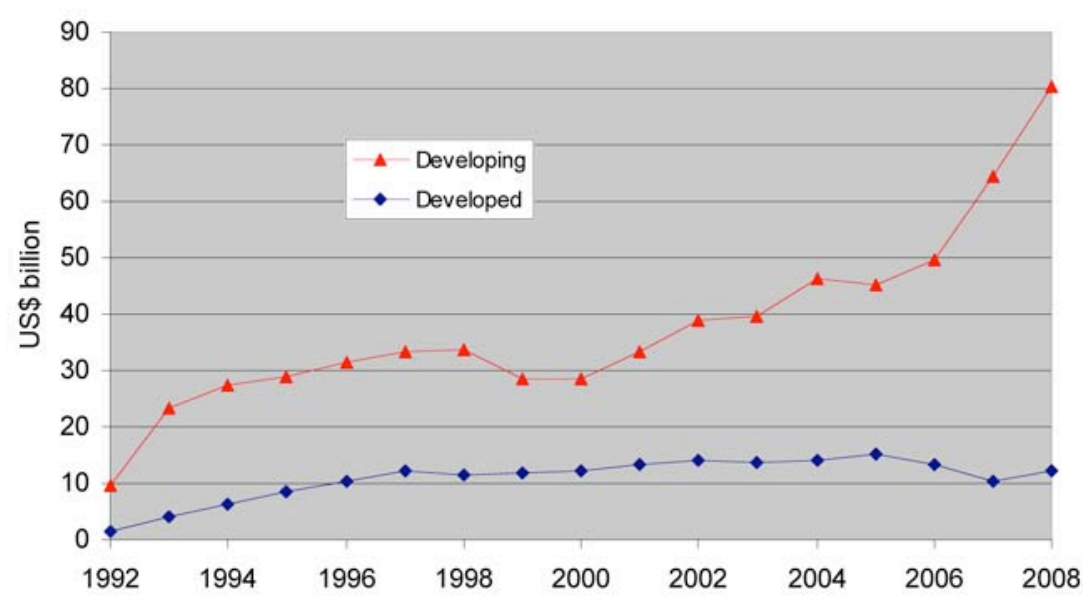

Sources: National Bureau of Statistics (NBS) various issues, China Statistical Yearbook, China Statistics Press, Beijing; Ministry of Commerce (MOFCOM) 2009a, 'FDI statistics', Invest in China, Ministry of Commerce, Beijing, viewed 21 May 2009, <http://www.fdi.gov.cn/pub/ FDI EN/Statistics/FDIStatistics/default.htm >

Unlike the 1997 East Asian financial crisis, which originated in developing economies and had a significant negative impact on FDI outflows from Asian developing economies, the current crisis began in the industrialised economies - in particular, the United States and the European Union - and this will substantially reduce the outward FDI flows from these economies.

In contrast, Asian economies, particularly the Asian developing economies, are the major sources for China's FDI inflows. As the Asian economies have suffered a lighter impact from the current crisis, their financial institutions are in better position than many of their counterparts in the Western industrialised economies. Although FDI inflows into China from Asian countries could decline moderately in the short term, as the impact of the current crisis recedes, Asian investments will recover and China's FDI inflows from Asian economies, especially Asian developing economies, will resume their robust growth. As a result, the current crisis will have a moderately negative impact on China's FDI inflows. 
Figure 15.5 FDI inflows and cross-border mergers and acquisitions in China (at current prices)

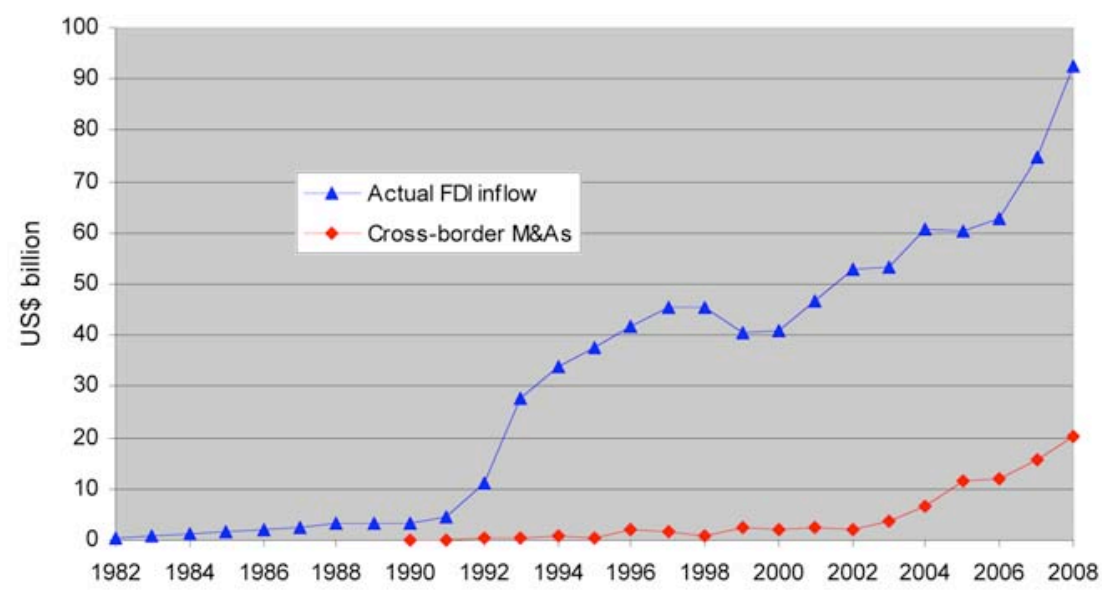

Sources: United Nations Conference on Trade and Development (UNCTAD) 2009, Assessing the Impact of the Current Financial and Economic Crisis on Global FDI Flows, United Nations, New York and Geneva, viewed 21 May 2009, < http://www.unctad.org/en/docs/webdiaeia20091 en.pdf >; United Nations Conference on Trade and Development (UNCTAD) various issues, World Investment Report, United Nations Publications, New York and Geneva.

\section{The entry modes of FDI in China}

FDI in China is overwhelmingly conducted through greenfield investment, which accounts for more than 95 per cent of FDI inflows into China. Crossborder mergers and acquisitions were prohibited in China before 1990. They were allowed in an experimental fashion in the 1990s, and started to increase only after 2002 (Figure 15.5). As not all cross-border mergers and acquisitions are related to FDI - especially for cross-border mergers and acquisitions in developing countries - the importance of cross-border mergers and acquisitions in FDI inflows to China has been very low. FDI inflows and crossborder mergers and acquisitions in China are, however, closely correlated and have moved in the same direction, especially since 2002 .

The relative importance of cross-border mergers and acquisitions to FDI inflows has been very low in China compared with the rest of the world. The ratio of cross-border mergers and acquisitions to FDI in the world was about 70 per cent and increased to more than 80 per cent after 2005 (Figure 15.6). In contrast, the ratio of cross-border mergers and acquisitions to FDI in China was below 5 per cent and increased to about 20 per cent after 2005 . 
Figure 15.6 The ratio of cross-border mergers and acquisitions to FDI in the world and China

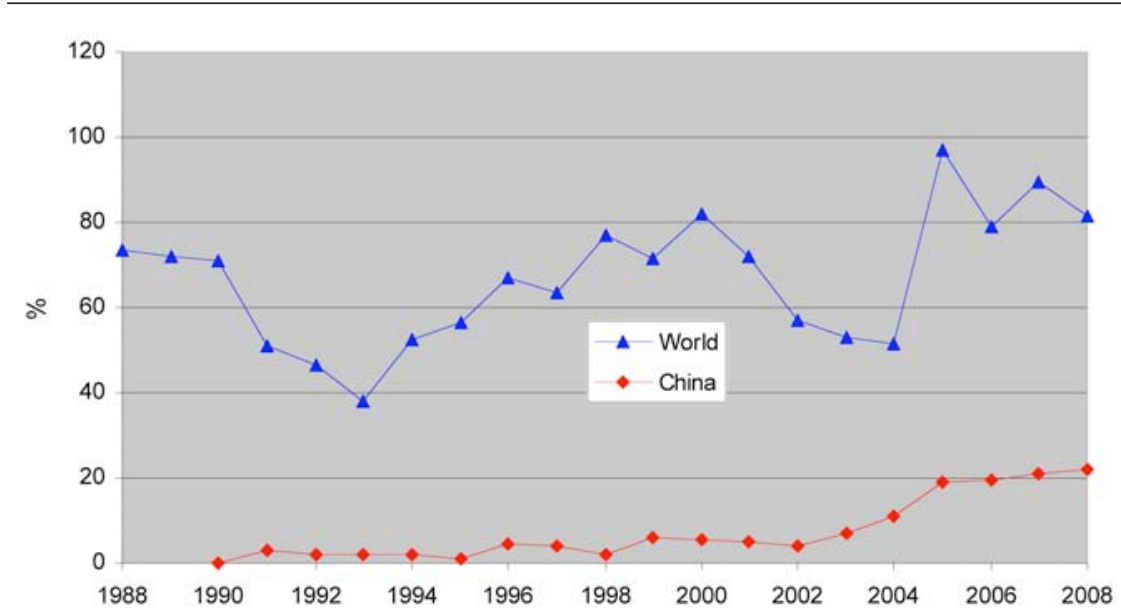

Sources: United Nations Conference on Trade and Development (UNCTAD) various issues, World Investment Report, United Nations Publications, New York and Geneva; United Nations Conference on Trade and Development (UNCTAD) 2009, Assessing the Impact of the Current Financial and Economic Crisis on Global FDI Flows, United Nations, New York and Geneva, viewed 21 May 2009, <http://www.unctad.org/en/docs/webdiaeia20091_en.pdf>

The current crisis will have a larger negative impact on cross-border mergers and acquisitions than on greenfield investment. Because FDI in China has been overwhelmingly dominated by greenfield investment and cross-border mergers and acquisitions account for only a very small share of total FDI inflows, the current crisis will have a moderately negative impact on FDI inflows into China. There are, however, also a lot of opportunities for cross-border merger and acquisition deals in China. As the Chinese Government further liberalises its policies, the momentum for cross-border mergers and acquisitions in China could remain strong. ${ }^{4}$

\section{Sectoral structure of FDI in China}

By the end of 2008, the sectoral distribution of FDI in China was characterised by its concentration in the manufacturing sector. The manufacturing sector attracted 63 per cent of the total FDI inflows into China during the period 1997-2008, the services sector attracted 35 per cent, while the primary sector attracted only 2.5 per cent. ${ }^{5}$ 
Figure 15.7 FDI inflows into China by sector (at current prices)

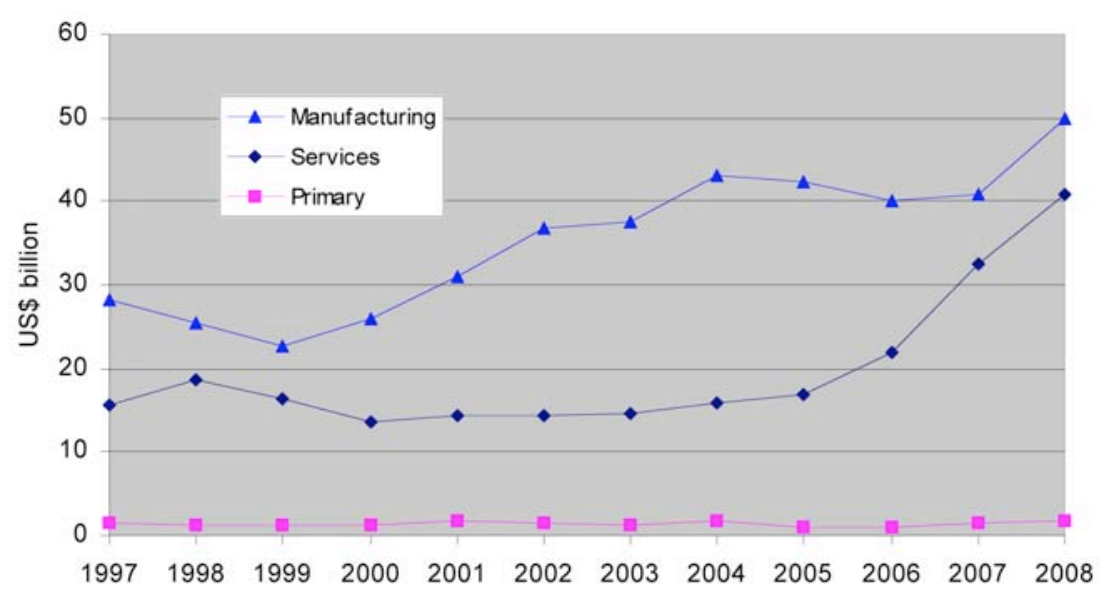

Note: Excluding FDI inflows into the financial sector (banking and insurance industries).

Sources: National Bureau of Statistics (NBS) various issues, China Statistical Yearbook, China Statistics Press, Beijing; Ministry of Commerce (MOFCOM) 2009a, 'FDI statistics', Invest in China, Ministry of Commerce, Beijing, viewed 21 May 2009, <http://www.fdi.gov.cn/pub/ FDI_EN/Statistics/FDIStatistics/default.htm >

The sectoral structure of FDI in China is different to that in the rest of the world, where the services sector accounts for more than 60 per cent of the total global FDI. The sectoral structure of FDI in China has, however, been gradually changing from a heavy concentration in the manufacturing sector towards increasing inflows into the services sector. Although the manufacturing sector continued to receive large amounts of FDI inflows after China's accession into the WTO in 2001, the growth rate of inflows into the manufacturing sector has slowed since 2004 (Figure 15.7). In contrast, FDI inflows into the services sector have increased rapidly since 2005. By 2008, the share of FDI inflows into the services sector increased to 44 per cent, while the share of FDI inflows into the manufacturing sector declined to 54 per cent. FDI inflows into the primary sector have been at a low but relatively stable level.

Undoubtedly, the current crisis will have a negative impact on FDI inflows into China in all three economic sectors. However, the extent of the impact on each sector will be different according to the nature of the FDI. 


\section{The manufacturing sector}

For the manufacturing sector, in terms of the capital to labour ratio, FDI can be classified into labour-intensive industries, capital-intensive industries and technology-intensive industries. In terms of the market orientation, FDI can be classified into domestic market-oriented FDI (market-seeking FDI) and export-oriented FDI (efficiency-seeking and resource-seeking FDI). In general, FDI in labour-intensive industries in China is aimed mainly at taking advantage of low labour costs in order to reduce production costs and increase competitiveness in the world market. Therefore, FDI in China's labour-intensive industries is mainly export oriented. In contrast, FDI in capital-intensive and technologyintensive industries is mainly looking at the Chinese domestic market, though there has been an increasing trend in exports of some products from these industries (for example, general machines, electronics, electric machines and equipment). Therefore, FDI in China's capital-intensive and technology-intensive industries is mainly market oriented.

In the past three decades, FDI inflows into China's manufacturing sector have gradually shifted from being heavily concentrated in labourintensive industries, which is mainly export-oriented FDI, towards more investment in capital-intensive and technology-intensive industries, which are mainly domestic market-oriented FDI.

From 1995 to 2006, the share of labour-intensive industries in the industrial composition of FDI firms in the manufacturing sector had declined while the share of capital-intensive industries - especially the share of technology-intensive industries - increased (Figure 15.8). The share of labour-intensive industries declined from 47 per cent in 1995 to 30 per cent in 2006, while the shares of capital-intensive and technologyintensive industries increased from 25 per cent and 27 per cent in 1995 to 31 per cent and 38 per cent in 2006, respectively.

The changing industrial structure of FDI firms - from their high concentration in labour-intensive industries towards more investment in capital-intensive and technology-intensive industries - is clearly an indication that FDI inflows have been increasingly targeting China's huge domestic market. In other words, more than half of the FDI in China's manufacturing sector is domestic market oriented and that share is increasing. 
Figure 15.8 Structural changes of FDI firms in manufacturing by total assets

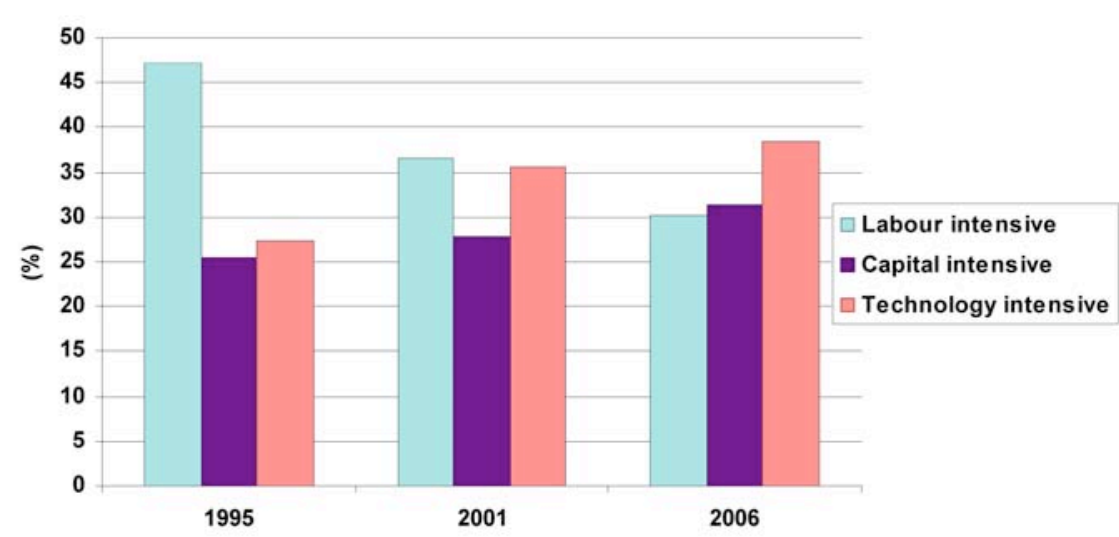

Source: National Bureau of Statistics (NBS) various issues, China Statistical Yearbook, China Statistics Press, Beijing.

The current crisis will have a large negative impact on market-seeking FDI in industrialised countries because of the expected negative economic growth there. Market-seeking FDI in developing countries, however, is expected to remain committed because of positive economic growth in 2009. This high economic growth will increase China's domestic market demand and provide good opportunities for market-seeking FDI. Therefore, market-seeking manufacturing FDI inflows into China are expected to experience a moderate decline or remain stable in 2009.

China's labour-intensive industries are quite competitive, with abundant and well-educated human resources and low labour costs, making China one of the most attractive locations for efficiency-seeking and exportoriented FDI. The current crisis will have a two-pronged impact on efficiency-seeking FDI in China. On the one hand, the weakening of the global economy - especially the severe economic recession in industrialised countries - has greatly reduced the external demand for China's exports. This will have a negative impact on FDI inflows into China's labourintensive industries. On the other hand, to reduce production costs and restructure global production, MNEs might shift their production from industrialised countries to developing countries. Undoubtedly, China will be one of the most attractive locations for efficiency-seeking MNEs' offshore production. Therefore, the current crisis will have some negative impacts on efficiency-seeking FDI inflows into China, but the impact will be moderate. 
In the first quarter of 2009, FDI inflows into the manufacturing sector were US\$12 billion. This represented a decline of 11.5 per cent from the same period in 2008, but decreasing by only 0.66 per cent from the average quarterly FDI inflows into the manufacturing sector in 2008. Against the general declining trend, in the first quarter of 2009, FDI inflows into some manufacturing industries even increased. For example, FDI inflows into the communication equipment, computer and other electronic equipment industry increased by 11.5 per cent; into the medical and pharmaceutical industry, they increased by 10.3 per cent; and into the general-purpose machinery industry, they increased by 6.2 per cent. FDI inflows into China's manufacturing sector are expected to remain relatively stable with a moderate decline in 2009.

\section{The services sector}

FDI inflows into China's services sector were about 32 per cent of total FDI inflows during 1997-2006 and increased to about 44 per cent in 2007-08. Among the services sector, FDI inflows into the real estate industry accounted for about 35 per cent during 1997-2006. In 2007 and 2008, FDI inflows into the real estate industry increased rapidly to about 50 per cent of the total FDI inflows into the services sector. Therefore, the sharp increase in FDI inflows into the services sector during 2007-08 was driven mainly by the large increase in inflows into real estate.

The large increase of FDI inflows into the real estate industry in recent years has two main causes. First, some foreign investors aimed to take advantage of the booming housing market in China, where house prices skyrocketed in the past couple of years. Second, some foreign investors were speculating on a sharp appreciation of the Chinese currency against the US dollar in order to make windfalls from the change in exchange rates. Obviously, such FDI inflows are not only speculative in nature, they are unstable. Therefore, the current crisis will have a large negative impact on such FDI. In fact, compared with the same period in 2008, in the first quarter of 2009, FDI inflows into the real estate industry declined sharply, by 38 per cent, which accounted for 61 per cent of the total decline of FDI inflows into the services sector. As a result, FDI inflows into other service industries declined only 12 per cent in the first quarter of 2009 compared with the first quarter of 2008, but actually increased slightly compared with the average quarterly FDI inflows in 2008. 
FDI inflows into China's services sector are mainly domestic market oriented. Although the value of China's services exports has been increasing since 2002, the share of services in China's total exports has been about 10 per cent and has shown a declining trend since 2003. Manufactured exports have grown more rapidly. The current crisis has had a large negative impact on FDI flows into the services sector, especially in financial industries such as banking and insurance, in industrialised countries. The impact of the current crisis on FDI inflows into the services sector in developing countries, however, should be relatively moderate because of the higher economic growth and the market-oriented nature of FDI in this sector. Therefore, it is expected that, except for the real estate industry, FDI inflows into China's other services sector will be relatively stable in 2009. If the Chinese economy recovers in the second half of 2009, the real estate industry will regain its attractiveness to FDI. Overall, FDI inflows into China's services sector could witness a relatively large decline in 2009, driven mainly by the decline in FDI inflows into the real estate industry.

\section{The primary sector}

FDI inflows into China's primary sector have been very low but relatively stable at about 2.5 per cent. They have been constrained more by institutional and policy factors than by economic factors. China's agricultural land tenure system and the traditional pattern of small-scale family-based agricultural production have greatly limited the inflows of agricultural FDI with large-scale production and advanced technologies. Therefore, China will not attract large amounts of FDI inflows into its agricultural sector without fundamentally changing its land tenure system and dramatically reforming the traditional farming pattern. China's FDI policies for mining industries are relatively restricted. According to China's Industrial Guideline for Foreign Direct Investment (amended in 2007), FDI is either restricted or prohibited in most mining industries, except for coal (excluding special coal), petroleum, natural gas, iron ore and manganese. Therefore, unless China liberalises its FDI policies for the mining industries, there will not be a large increase in FDI inflows. Consequently, the current crisis will have a marginal impact on FDI inflows into China's primary sector. 


\section{Prospects for FDI inflows into China}

The current crisis has greatly reduced global economic growth, particularly in the industrialised countries. As a result, external demand for China's exports has been negatively affected. The external demand for China's exports has been a very important component of China's high economic growth. The contribution of net exports to China's GDP growth was, on average, about 20 per cent during 2005-07. Apart from the direct contribution of exports to China's economic growth, there have been a lot of indirect economic activities generated by the export sector. For example, large portions of local services and local investment are connected with export industries, whose employees also generate multiplier effects in the economy.

One of the major risks to China's economic recovery from the current crisis and its overall economic growth lies in the external side and China could undergo long-term economic and structural adjustments given the fact that its major trading partners - the United States, Japan and the European Union - could take three to five years to come out of recession. ${ }^{6}$ Therefore, a full recovery of China's economy will depend on developments in the world economy, particularly the advanced economies.

In the first quarter of 2009, China's exports continued to fall-by 20 per cent - compared with the same period in 2008. The negative impact on exports was much more severe for foreign-invested enterprises (FIEs). The exports of FIEs decreased by 23 per cent in the first quarter of 2009, compared with the same period in 2008. Undoubtedly, this will have a negative impact on the ability of labour-intensive and export-oriented manufacturing industries to attract FDI inflows.

While the current crisis will continue to generate negative impacts on FDI inflows into China, various positive factors are also at work and will attract inflows in 2009 and coming years.

There are a number of reasons why MNEs might remain committed to investing in China. First, China's overall investment environment is quite competitive. Relatively efficient public services, good infrastructure, a large and rapidly growing domestic market, abundant and well-educated human resources, low labour costs and macroeconomic and political stability - make China one of the most attractive locations for FDI. 
China, as the largest developing and fastest growing economy, has remained attractive to FDI, particularly to market-seeking FDI. As economic prospects continue to deteriorate in industrialised countries, investors will favour the relatively more profitable options available in developing countries. A survey by the US-China Business Council in March 2009 revealed that 88 per cent of foreign businesses in China were profitable, 81 per cent had a higher profit margin in China than elsewhere and 89 per cent selected China as their first-time investment location ('China's FDI decline slows in March', Xinhuanet, viewed 21 May 2009, $<$ http://news.xinhuanet.com/english/2009-04/14/content_11181782.htm>).

China's abundant and relatively well-educated labour force and its low labour costs remain attractive to labour-intensive and export-oriented FDI projects. China's labour-intensive products are mostly daily consumer goods, which have a relatively low elasticity of demand. Therefore, the negative impact of the economic recession on demand for China's labour-intensive products is relatively small compared with luxury consumer goods. In April 2009, although China's total exports continued to decline by 5.5 per cent from March, exports of some major labourintensive products actually increased. For example, exports of textiles and clothing increased by 7.6 per cent, furniture increased by 2.7 per cent, footwear increased by 3.8 per cent, suitcases and handbags increased by 22.4 per cent and toys increased by 18 per cent (MOFCOM 2009b). This is a good sign that exports of labour-intensive products will lead the overall recovery of China's exports and it is also a positive signal to efficiencyseeking FDI to increase investment in China's labour-intensive industries. Therefore, China will continue to attract efficiency-seeking FDI inflows, including the diversion of efficiency-seeking FDI from industrialised and other developing countries.

China has implemented a series of favourable FDI and trade policies that will have a positive impact on FDI inflows. China decentralised FDI approval rights in March 2009 and provincial authorities now have the right to approve FDI projects of less than US\$100 million. China has increased the tax rebate for exports six times since 2008 for some export products. As a result, the comprehensive tax rebate reached 12.4 per cent. ${ }^{7}$

China has been arranging currency swaps with trading partners to bypass the US dollar in trade settlements. These swap accords allow overseas central banks to sell the renminbi to local importers who want to buy Chinese goods. Since mid-December 2008, China has signed currency 
swap contracts worth RMB650 billion (US\$95.6 billion) with central banks in Hong Kong, South Korea, Malaysia, Belarus, Indonesia and Argentina. In April 2009, the Chinese State Council gave the green light to five major trade cities - Shanghai, Guangzhou, Shenzhen, Zhuhai and Dongguan - to use the renminbi as an option to settle international trade deals. A similar arrangement has been proposed for exporters in Guangxi and Yunnan in southern China, who will be allowed to use the renminbi to settle trade with Association of South-East Asian Nations (ASEAN) members from 2009. These arrangements will benefit manufacturers and traders at home and abroad by reducing their exposure to exchange rate volatility, increasing liquidity in foreign trade and reducing consumer burdens ('Yuan edges into place as international trade currency', Xinhuanet, viewed 21 May 2009, <http://news.xinhuanet.com/english/2009-04/16/ content_11194529.htm $>$ ).

China has also implemented a series of concrete measures to facilitate trade, especially exports - for example, by supporting small and mediumsized enterprises (SMEs) to explore international markets, especially new markets in emerging economies, which will cover 80000 SMEs in 2009; adjusting processing trade category lists, by dropping 27 categories from the prohibited list and 1730 categories from the restricted list; and improving trade facilitation by reducing red tape in customs procedures (MOFCOM 2009b). These policy changes are necessary to deal with the current crisis, increase exports and boost economic growth, which will have a positive impact on attracting FDI inflows.

\section{Conclusion}

The current crisis has severely affected the world economy as well as global FDI flows. As the impacts of the continuing crisis unfold, the global economy is expected to shrink by 1.3 per cent and global FDI flows are expected to decline by 25 per cent in 2009. As the third-largest economy in the world and the largest FDI recipient among the developing countries, China is not immune to the current crisis. Its economic growth is expected to decline from a high of more than 10 per cent annually in the past decade to about 8 per cent (the level set by the Chinese Government) or 6.5 per cent (forecast by the IMF) in 2009. FDI inflows into China have also been negatively affected by the crisis, especially since October 2008. Compared with the sharp decline of global FDI inflows, however, the negative impact of the current crisis on FDI inflows into China has been moderate. Why 
have FDI inflows into China been resilisent and what will be the impact of the current crisis on inflows in 2009?

Industrialised countries have been hit directly by the current crisis, while developing countries have been affected only indirectly. As a result, FDI inflows into China from industrialised economies - particularly from the United States and the European Union - will decline by a relatively big margin, but FDI inflows from developing economies, particularly from the Asian developing economies, are expected to decline only moderately. Because about 80 per cent of FDI inflows into China come from developing economies, the overall negative impact of the current crisis on FDI inflows into China will be moderate.

The current crisis will have a larger negative impact on cross-border mergers and acquisitions than on greenfield investment. On the one hand, leveraged buy-outs - a common transaction method in cross-border mergers and acquisitions - have fallen considerably due to weakened world stock markets. On the other hand, the deterioration of the external funding environment has also made it more difficult for MNEs to make cross-border merger and acquisition deals. In contrast, the impact of the current crisis on greenfield FDI projects has been limited. Because more than 95 per cent of FDI inflows into China are greenfield investments, the negative impact of the current crisis on overall FDI inflows into China is therefore expected to be moderate.

The current crisis will have a moderately negative impact on FDI inflows into China's manufacturing sector, mainly on efficiency-seeking manufacturing FDI. The impact of the current crisis on FDI inflows into the services sector will be larger than that on FDI inflows into the manufacturing sector; however, most of the negative impact will be on FDI inflows into the real estate industry. FDI inflows into the other service industries are expected to remain stable. Finally, the impact of the current crisis on FDI inflows into the primary sector will be marginal given the institutional and policy factors affecting FDI inflows in the primary sector in China.

This study therefore estimates that FDI inflows into China will most likely be about US $\$ 85$ billion in 2009 - a moderate decline of 8 per cent from 2008. 


\section{References}

International Monentary Fund (IMF) 2009, 'Crisis and recovery', World Economic Outlook, April 2009, International Monentary Fund, Washington, DC, viewed 21 May 2009, < http://www.imf.org/external/ pubs/ft/weo/2009/01/pdf/text.pdf>

Ministry of Commerce (MOFCOM) 2009a, 'FDI statistics', Invest in China, Ministry of Commerce, Beijing, viewed 21 May 2009, <http://www.fdi. gov.cn/pub/FDI_EN/Statistics/FDIStatistics/default.htm $>$

2009b, Regular news conference, Ministry of Commerce, Beijing, 15 May 2009, viewed 21 May 2009, <http://www.mofcom.gov.cn/aarticle/ ae/ah/200905/20090506252069.html>

National Bureau of Statistics (NBS) various issues, China Statistical Yearbook, China Statistics Press, Beijing.

United Nations Conference on Trade and Development (UNCTAD) 2009, Assessing the Impact of the Current Financial and Economic Crisis on Global FDI Flows, United Nations, New York and Geneva, viewed 21 May 2009, <http://www.unctad.org/en/docs/webdiaeia20091_en.pdf> various issues, World Investment Report, United Nations Publications, New York and Geneva.

\section{Endnotes}

1. One such example is Pacific Brands, an Australian multinational textile and clothing company, which has closed its production in Australia and is shifting its manufacturing operations to China for price reasons ('Pac Brands exits Australian manufacturing', Sydney Morning Herald, 25 February 2009, viewed 21 May 2009, <http://business.smh.com.au/ business/pac-brands-exits-australian-manufacturing-20090225-8hei.html>).

2. The data do not include FDI inflows into the financial sector (banking and insurance industries).

3. Calculated from National Bureau of Statistics (NBS) various issues, China Statistical Yearbook, China Statistics Press, Beijing; Ministry of Commerce (MOFCOM) 2009a, 'FDI statistics', Invest in China, Ministry of Commerce, Beijing, viewed 21 May 2009, <http://www.fdi.gov. cn/pub/FDI_EN/Statistics/FDIStatistics/default.htm> Note: calculations are based on 2000 constant US dollar prices

4. One example is the acquisition deal proposed by the Coca Cola Company to buy China Huiyuan Juice Group Limited for US\$2.4 billion in early 2009-although the Ministry of Commerce of China rejected the deal.

5. Data for real FDI inflows by sector are not available before 1997. Calculations are based on 2000 constant US dollar prices. 
6. In 2007, the United States, the European Union and Japan accounted for 19.14 per cent, 18.19 per cent and 8.38 per cent, respectively, of China's total exports. In aggregate, these three major trading partners accounted for 45.71 per cent of China's total exports in 2007.

7. The full tax rebate for exports is 17 per cent. 